\title{
Vocal Piano Accompaniment: A Constant Research Towards Emancipation (2)
}

\author{
Jose Maria Peñalver Vilar ${ }^{1}$, Luis Valles Grau ${ }^{2}$ \\ ${ }^{1}$ Education and Specific Didactics Department, Universitat Jaume I, Castellón, Spain \\ ${ }^{2}$ Music Department, Valencian International University, Valencia, Spain
}

Email address:

penalver@edu.uji.es (J. M. P. Vilar), luis.valles@campusviu.es (L. V. Grau)

To cite this article:

Jose Maria Peñalver Vilar, Luis Valles Grau. Vocal Piano Accompaniment: A Constant Research Towards Emancipation (2). English

Language, Literature \& Culture. Vol. 5, No. 1, 2020, pp. 25-35. doi: 10.11648/j.ellc.20200501.13

Received: December 30, 2019; Accepted: January 16, 2020; Published: February 4, 2020

\begin{abstract}
This is the second and last article in the series dedicated to the investigation of the evolution of vocal piano accompaniment through history and the role-played by the piano in its relationship with the voice. If the previous chapter focused from the beginnings of piano accompaniment to Franz Schubert, this one will take up again the analysis of the piano part from the last lieder of Franz Schubert to Arnold Schoenberg. The research method used continues to be based on the musical analysis of the piano part, addressing both issues of the piano itself and its link with the text and the vocal part. By means of musical examples of different composers, the article investigates all those aspects that provide evidence of the change in the role of the piano in the correspondence of the piano with the voice and its repercussion on the final result of the work. In this way, we will look at the history of piano accompaniment for voice and see how the influence of Schubert's conception of vocal piano accompaniment materializes in contemporary and later composers, as well as the crucial change in the history of the piano as an accompanying instrument introduced by Schubert. The results and conclusions drawn from the evolution presented in these two articles are presented at the end of the article, based on the different aspects involved in the musical event, such as rhythm, harmony or texture.
\end{abstract}

Keywords: Piano, Music, Accompaniment, Voice, Schubert

\section{Introduction}

We take up the investigation of the first article, continuing with examples from Franz Schubert to the end of the 20th century. At the end of the investigation we present the results and conclusions. With the help of a theoretical framework and the exemplification of scores we can see how it has evolved the voice's piano accompaniment. Throughout two articles we will see how the conception of the piano in its participation in voicepiano duo suffered, with Franz Schubert, a turning point that marked his future. To do this we would like to start this article explaining what the practice's accompaniment is because it will help to understand its historical evolution in relation to the song.

\section{Examples}

\subsection{Franz Schubert}

In the previous article we examined Der Erlkönig, now we present Die Stadt. It is confronted with Schubert's temporary approach. In this new example the nuance added on this occasion is that the two pillars of his music are made up of the voice and the piano. Singing represents the whole time, that is to say, the past, the present and the future. Rhythmic writing, ostinato, reiteration and the obsessive are provided by the piano. In this way, the real protagonist of the lied is time. In Die Stadt the listener never knows what will happen next. In this way, Schubert lays the foundations for the new spatial-temporal conception of music in the 19th century [1].

This spatiotemporal consideration is also undoubtedly influenced by Heine's text, which is sometimes so ironic in considering the present as a past and laughing at it through metaphors such as that of the lover disillusioned in the past reviving that situation in the present [2]. Schubert currently uses an ambiguous harmonization, with open chords and distant tonalities. Instead, tonal clarity appears in the scenes where mirage and memory are unveiled and reality is returned. But Schubert always leaves us the doubt when in 
the final stanza the tension is diluted and seems to make us doubt that this illusion really existed, wondering what was real, if the imaginary or the earthly. This theatricalization together with the harmonic-tonal game is undoubtedly one of Schubert's most remarkable characteristics [3].

The beginning, with a single note in the grave and pianissimo, leaves open the infinite possibility of the entire universe. This ambiguity remains two measures. In addition, in the third, an arpeggio of a sensitive seventh chord appears in the right hand, so we continue with greater uncertainty. The introduction ends as it began, with only one tremolo note in the low register.

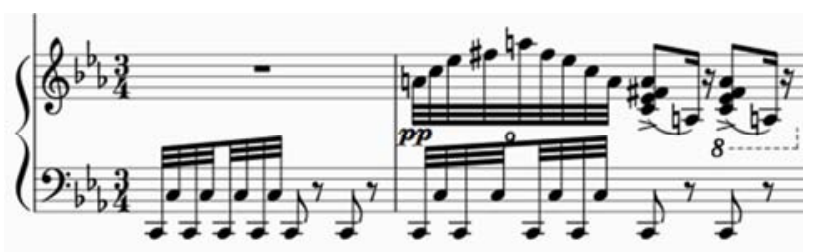

Figure 1. Measures 2 and 3.

We have seen many examples of how Schubert uses the tremolo, but at this moment he combines it with silences and with a completely open harmony. He has combined a rhythmic ostinato with an open harmony. The result of the ensemble is disturbing, it generates a lot of expectation, since everything is open, and everything is possible [4].

It is the voice that gives reality to the lied. Therefore, in this lied the piano has a character role within the poem. Schubert has added narration to the poem by including the piano in the story. The character of the piano character gives another dimension to the poem. When the voice enters, it abandons the tremolo and presents us with the quaver rhythm with semiquaver that we have commented on so much. He will adopt it in a homophonic way between the voice and the piano throughout the first stanza.

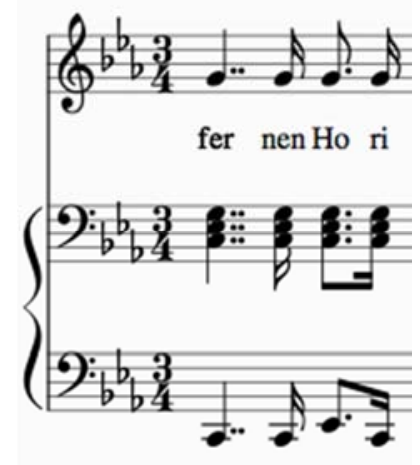

Figure 2. Measure 7.

Once the first stanza is finished, he resumes the introduction and, while the second stanza runs, he maintains the tremolo of the left hand in the first beat and the arpeggio of the seventh chord of sensible in the right hand. The second and third beats have negras (quaver with quaver silence) in the left hand and the previously arpeggiated chord, placado in the right hand, exactly as in the introduction.

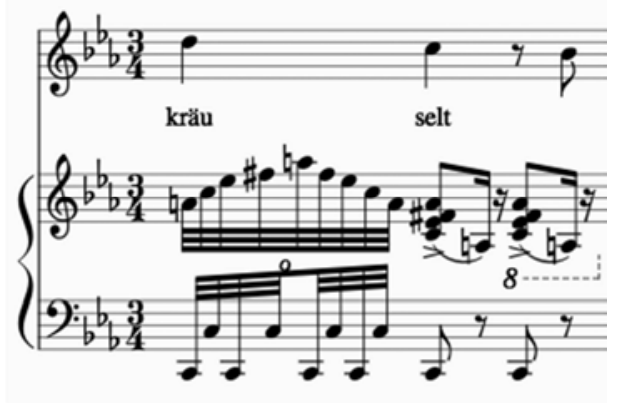

Figure 3. Measure 19.

In the third stanza he has again the material of the first one with variations both in the voice and in the piano and concludes the piano as it had begun: pianissimo and with the tremolo in the left hand and the arpeggioed in the right hand.

The dramatic tension is concentrated on this lied in the second stanza. We appreciate again that it places this tension in the moments of more action of the poem. In this it is the wind that whips up all the drama of the story. The piano is impassive. It is not an ostinato, but to maintain the same exact model that we have related previously: tremolo in left hand and chord of seventh of sensible in the arpeggioed right hand or placado. On this pattern it is the voice that agitates the whole speech. It is about redefining a type of recitative. If in the Baroque and Classicism it was constituted from a chord that played the basso continuo or the piano at the same time or before the voice and later left the voice free to express itself with total autonomy, Schubert has, through a rhythmic-harmonic ostinate, the ideal stage for the voice to perform the same declamatory function, but with greater expressiveness, thanks to the involvement of the piano. All the notes of the voice are part of the seventh chord of sensible, except for a few notes of passage and especially an appoggiatura in the second measure of this second stanza. At this moment, in 'kräuselt', 'encrespa', in measure 19, Schubert wants to emphasize it expressively with a dissonance. We can see this in the previous figure 3. It always enhances in some way everything that is relevant to the narration, and at this moment the action of wind frizz is undoubtedly fundamental because of the effects it produces on the protagonist.

The voice range is one tenth, from low $C$ to high $E b$. To a greater extent it is below the tessitura of the piano, so it should highlight its lower timbre. Therefore, Schubert's sound design for this dark stanza is one of total uneasiness due to the insecurity caused by the wind. The piano we said at the beginning of this lied, is who embodies the obsession, the supernatural. In this second stanza it is evident what unwritten role the piano plays.

At the end, in the third stanza, he repeats the melody of the first. However, as the character of the text does not correspond to the first, Schubert introduces important variations. The first is the indicative of the voice in reference to the character. In the first one he indicates 'leine', 'soft', while in the third one he demands 'stark', 'hard'. Apart from the fact that both the voice and the piano must impress him, the most notable differences are the inclusion of triplets in 
the voice, the sixth Neapolitan of measure 32 and the high $G$ that appears in this stanza. This high point is not arranged anywhere else but in his beloved, having a rhythm in addition to white, the only one in the whole lied both in the piano and in the voice. As in the silences, at this moment the whole motor of the lied stops to express to its beloved, the pain of the protagonist for not remaining next to her.

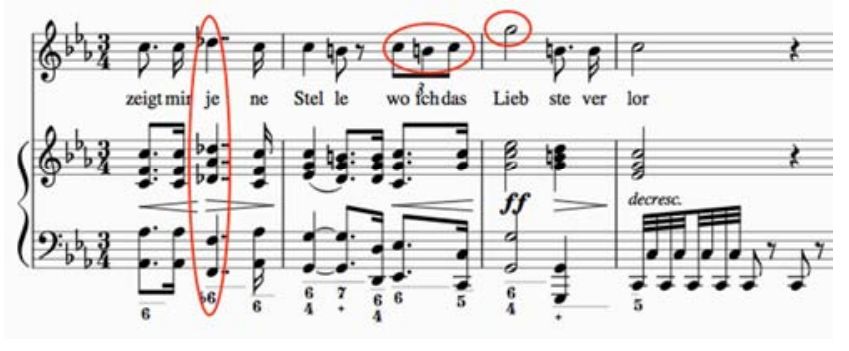

Figure 4. Measures 32 to 35 .

The two points at which the triplets are placed in the voice are each unique. The first, in measure 29 , refers to the ascent of the sun, of light, of hope. The second, in measure 33, refers to the rhetorical place where he thinks his beloved is. On the other hand, the piano remains impassive with the eighth note meter with a sixteenth note. If in the first stanza piano and voice went hand in hand, in this second one we see how piano and voice in some moments distance themselves. As in the second stanza, the piano functions as an impassive, obsessive, supernatural character. It takes on a new dimension in Schubert's poem [5].

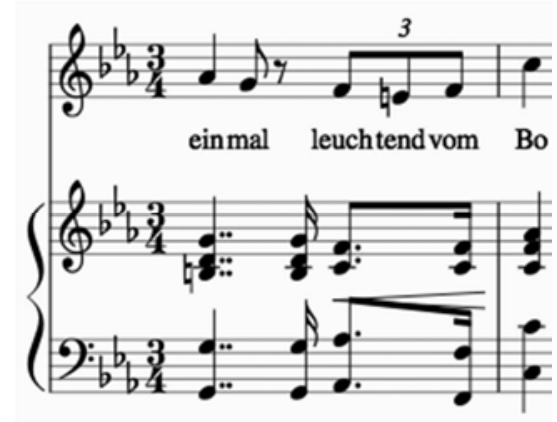

Figure 5. Measure 29.

\subsection{Richard Wagner and Hugo Wolf}

The Wagnerian heritage made the continuity of the lied as we knew it somewhat problematic. In the following example we want to illustrate with Hugo Wolff (1860-1903), the personification of the reality that Wagner left in the field of the lied. Halfway between pure romanticism and new horizons, he follows the lines of Schubert, Schumann, Wagner and Liszt. He is the most important composer of Lieder since Schubert, and both represent the pillars of the liederistic genre. Wolf presents a few works for voice and piano, but with greater impact on the lied, later influencing Debussy. He crossed the limits of tonality with an intensely expressive language and integrated the essential elements of the romantic lieder tradition. Wolf turned the lied into a miniature opera, condensing in a few seconds the intensity of a drama [6].

The difficulty of the piano writing of Wolf's Lieder is by no means gratuitous and always responds to an expressive need. The harmonic complexity expresses poetic symbolism. The line of the piano evolves in the line that Schubert initiated: the equalization of voice and piano. In Wolf's lieder this union is achieved through a great interest in poetry. For this reason, the piano must adapt the sound to the colour of the voice, transforming the text into music and creating a suitable atmosphere. It should be noted that Wolf was a poet who thought with reference to music and not the other way around. Especially Schubert, but also Schumann or Brahms, had a special sensitivity for poetry; Wolf takes this conception further. Music feeds on the essence of poetry, assimilating the rhythms, tones and cadences of poetry and language [7]. The vocal melody becomes a part of the whole, as in Wagner's concept of total work of art. He described the text-music relationship based on metaphors of organic unity. From the interest in the melody itself, Wolf composes the melody only as one of the elements necessary to underline the meaning of the poem. We come to the point we have been announcing: the piano part has nothing to do with accompaniment; it is the dramatic commentary of the poem. We have seen this statement evolve in Schubert and Schumann. If Wagner created the idea of a total work of art in the orchestra, Wolf did so in the lied, taking the consequences of chromaticism even further. $\mathrm{He}$ added another dimension to the lyrical line. Like Wagner, Wolf was the greatest exponent of pictorial expressionism in music, and more specifically in the lied. His way of expressing despair, tragedy or irony resulted in a new conception of the lied as form, starting from the hegemony of the piano as an accompanying instrument initiated by Schubert [8].

He continued Schubert's theatrical line through the idea of a total work of art enhancing the dramatic and theatrical dimension of Lied. He introduced in the lied a form of melodic declamation, inherited from Wagner, basing the melodic line on the accents of the spoken language and the sense of the phrase and not on the metric of the verse as until then. The musical symmetry of Schumann or Brahms disappears. Wolf determines the form of the music through the form of the poem. He was a creator rather than a conservative, elaborating his own models to express what the verse says. Sometimes he sacrificed melody to expression in almost spoken intonations announcing Schoenberg's language, the Sprechgesang [9].

The period in which his musical mastery manifests itself begins in 1888 with Mörike's songs. Most of them were written in Perchtoldsdorf, next to Vienna, where a friend of his, the lawyer Heinrich Werner, had a country house. There Wolf, as seldom in his life, was happy [9]. We present three lieder from this series of songs: Der Genesene an die Hoffnung, Um Mitternacht and Lied vom Winde. The first one talks about hope. For this the piano begins in the bass with unison in pianissimo. 


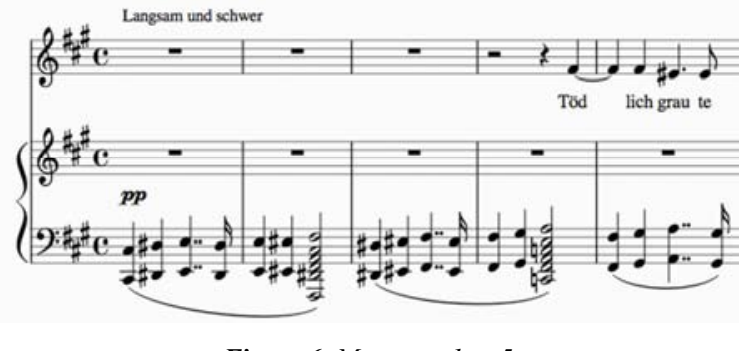

Figure 6. Measures 1 to 5 .

As we have already pointed out, Wolf takes to the maximum the characteristic of the dramatization that we have commented so much. From the beginning of the piano to the $G \#$ of the voice in measure 13 , we have witnessed a fullyfledged progression. From the darkest darkness to which the voice also joins in a low register, passing through the textures of unison and chorale of the piano. Harmony accompanies this task. We find it full of appoggiatura, but with only one modulation in this first part in $E$ major. The unison of the piano, as if it were a cantus firmus, accompanies us six measures. From then on, the instability increases greatly: syncopation in the melody, abandonment of the low register, the appearance of more voices on the piano.

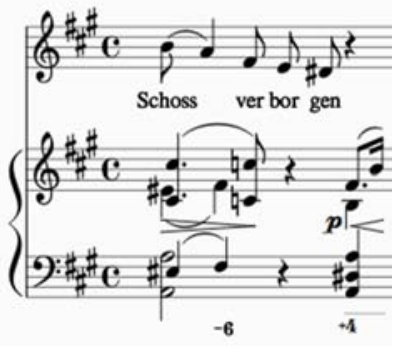

Figure 7. Measure 10.

In the following verses, the piano acquires a quaver pulse in the right hand, striking the harmony. Between the first and second stanzas, the piano has performed a small interlude, while the third and fourth stanzas are followed. After the harmonic stability we commented on in the first stanza, in the second part of the lied, where the remaining stanzas are housed, instability is a constant in all senses. The concept of tonality is being diluted in Wolf. From initial $F \#$ minor we have modulated to $E$ major. On the other hand, the second stanza starts the voice returning to $F \#$ minor, to change the two measures to $B b$ minor through harmonization and chromatic modulations. We are immersed in an absolutely dreamlike atmosphere.

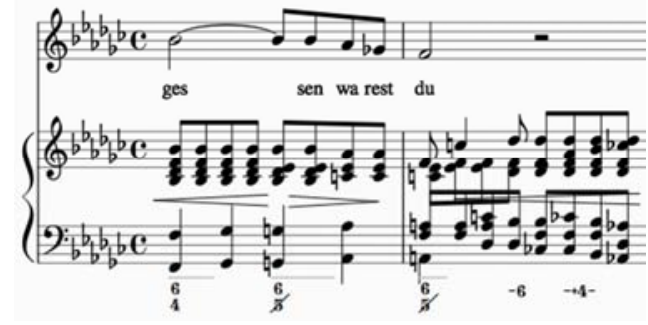

Figure 8. Measures 20 and 21.
From the piano, which had begun this second stanza in $E$ major with black, some eighth notes sprout with the dominant $F \#$ minor, and from which everything is enlarged. There are more and more voices, in the same way that we have noted in the first stanza and the registers are widening and distancing. We already find bass, middle and treble, and the eighth notes are no longer made exclusively by the right hand but by both hands. The first climatic point is in measure 13 , in the repetition of 'Stegge', 'victory' in German. The next, in measure 23 , has been preceded by no more accumulation of tension, although it is true that the first reaches the fortissimo, and in the second a single $f$. Wolf puts more emphasis on the initial victory than on the eternal saviors. From this moment on we begin another process.

The interlude between the second and third stanzas brings us closer to both Wagner and Debussy. Wolf surprises us with a passage without the bass until the voice is incorporated and arranges a whole framework of two voices in dialogue in the right hand next to the harmony in quavers of the left hand.

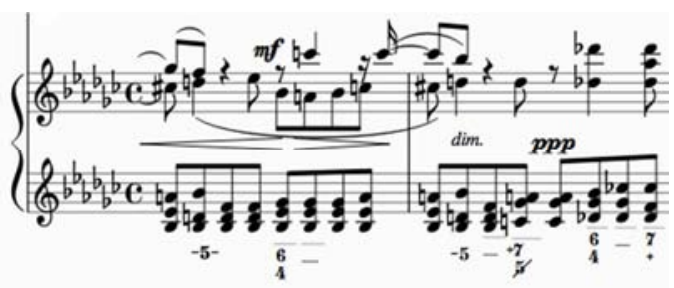

Figure 9. Measures 26 and 27.

It doesn't take much imagination to realize the orchestral nature of this passage. The different imitations between each other, also between the piano and the voice, as well as the syncopations, give us information on how Wolf works the processes. These are brief developments in which he condenses the entire content of the poem. Let us remember that for Wolf poetry weighs more than music. In this case, the piano adapts to the text, not to the voice. Therefore, both voice and piano are servants of words. He is a playwright of music.

Of the syncopations and setbacks that the piano starts having, then the voice presents them and then both at the same time, we arrive in the last stanza at maximum instability, with syncopations both in the voice and in the piano. Wolf writes 'sehr innig', 'very deep', and in a piano nuance that culminates in forte, although without the expressiveness of the previous two points. They are two measures of dense anxiety begging, begging to alleviate the pain.

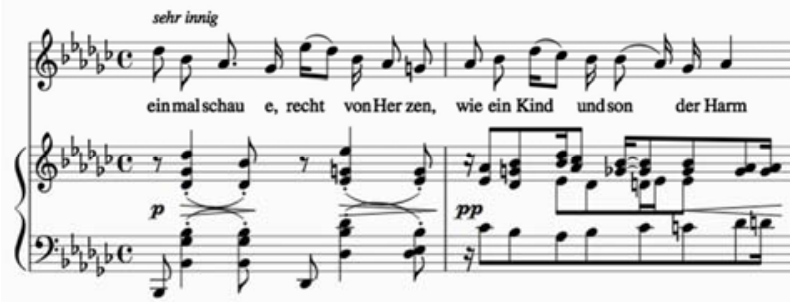

Figure 10. Measures 34 and 35. 
The piano ends in syncopations in the grave register, as it did at the beginning. The voice, on the other hand, ends with the lowest note of the whole lied. The tessitura of the lied covers practically two octaves, although the most important thing about the voice is the instrumental character that Wolf gives it. It is another element next to the piano of dramatic expression.

\subsection{Maurice Ravel}

In the following example belonging to Maurice Ravel we can see the bridge built by the Impressionists towards the Post-Impressionists. He lived between 1875 and 1937 and his work for voice and piano occupies an important place in his production. It is not abundant, but it does advance within the line proposed by Schubert. He was able to adapt his style to the text and the poems he selected. He conceived of the lied, the mélodie, as a whole, where voice and piano play the same role. For this reason, we affirm that he is heir to the idea that Schubert established and that Ravel developed in a very particular language [10]. Halfway between impressionism and contemporary German music, we present Les grands vents venus d'outremer... It was written in 1906. Let's note that it was composed prior to the one we have commented on by Richard Strauss, considered the latter Romantic and Ravel Impressionist. The text is from the Tel qu'on songe collection of the Symbolism poet Henri de Régnier published in 1892. Its reference writer had been Mallarmé, but on this occasion he chose Réginer, and at the piano level we are more interested in showing this example than other pieces [11].

He starts from the premise of making music speak: he is a poet of music. This is the origin of his approach to an orchestral piano. Thanks to Beethoven and Schubert's approach, he makes the piano reach new sonorities. The entire piano part is based entirely on a romantic chromaticism. The writing on this page is completely tormented. He wrote it after the last proposal for the Rome Prize and after having composed melodies with orchestra. Already the beginning is a gloomy chromatism that in the time of a black passes from piano to forte. The piano, in its introduction, prepares the atmosphere with which the voice will be found.

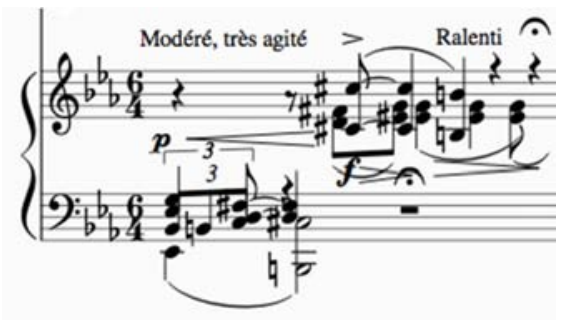

Figure 11. Measure 1.

From the coral and vertical texture of the first two measures, it passes in the left hand to move the waters in an arpeggiated ostinato of harmony that collaborates in the general agitation of this first stanza.

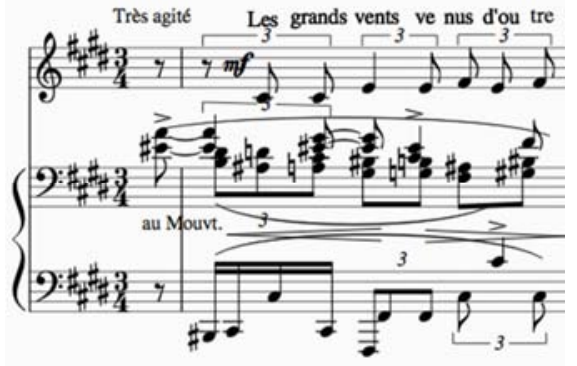

Figure 12. measure 3.

Subsequently, to finish it and link it to the second of a calmer nature, it slows down the tempo and figuration. Here we find again a control of the space-time game of which we have spoken so much with Schubert. The whole first stanza is a constant agitation in a gloomy sonority. Both the voice and the piano are in a low register that conveys an absolutely dark sensation to the listener.

The sea has been a constant source of inspiration for musicians. The metaphor of the great winds coming from the ultra sea takes us to the exotic, to the distant, and this is how the voice begins, in a diffuse and grave timbre. Lover of the middle register does not present great stridency. Except for the fortissimo in measure 17 , the rest of the melody of the voice is a recitative in declamatory style. Meanwhile, the piano has, up to measure 17 , a very wide choral texture with mordent basses.
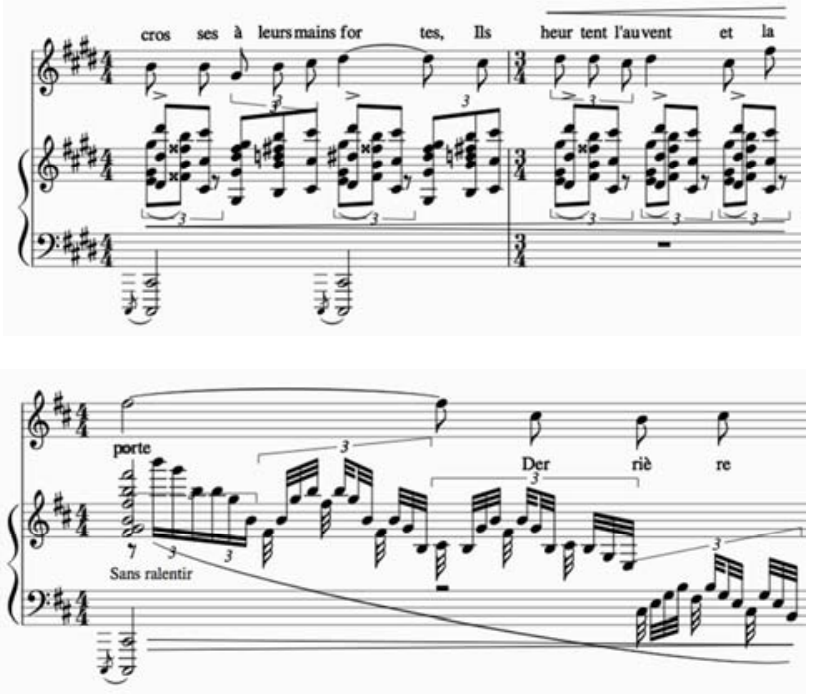

Figure 13. Measures 15 to 17.

In the second stanza, the rhythm changes to 'trés lent' in measure 9, and the writing expands to three staves. We return to choral texture with chords of eight notes plus bass, i.e. practically orchestral amplitude. In the first stanza we had had some simultaneous or displaced unison as a result of opposing movements between voices. For example, in the third measure the right hand has a descending movement in front of the ascending voice. We can see it in figure 12. Both are in the $E$, although rhythmically they do not correspond. In the next measure, the fourth, they do go in unison, in sound 
and pulse. At this point we must add the response of the piano in measure 5.

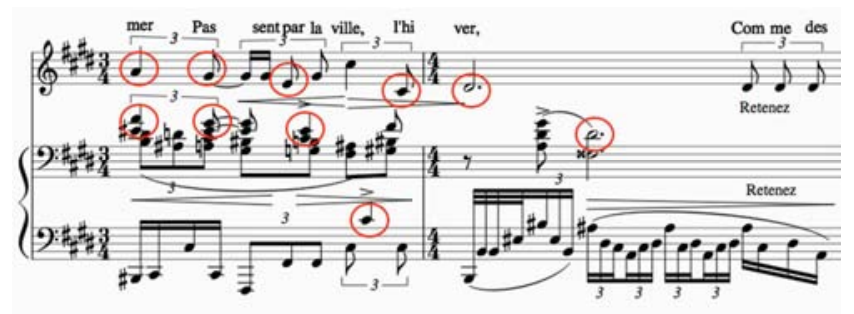

Figure 14. Measures 4 and 5.

Well, in the second stanza he only outlines a few notes of the voice, such as the first one he starts with or the $E-E b$ chromatism of the next measure.

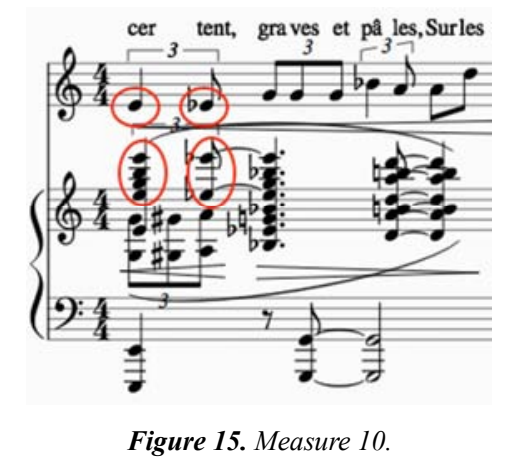

On the other hand, in the third, when the 'agité' returns, the redoubling of the piano to the voice is supported by an ostinato that repeats the piano to the margin of the voice in measures 14 and 15 . We can see it in figure 13. In this ostinato the voice is found to reinforce more if possible the crescendo and the agitation, obtaining in measure 17 a full burst that gives it the spatial timbre dimension of eight octaves and the disintegration in arpeggios of the right hand, unfolding all the harmony. It is a very virtuous passage. It is in this third stanza that he returns to the agitation of the first and culminates in the fortissimo of measure 17 that we commented on. In order to do this, he again resorts to the texture of placados chords, adding the bass in mordentes. To finish he prepares a recitative to the voice wrapped in a sonority characteristic of Ravel and ends with the choral texture of the beginning, although in a not so deep register.

In our opinion, this lied faithfully reflects Ravel's entire compositional style, as well as the confirmation of the role that vocal composition plays for him. In the same way, the role he gives to the piano is at all times a major protagonism, although it gives the voice all the expressiveness it can offer.

\subsection{Arnold Schoenberg}

We have come to the end of the relationship of the voice with the piano to this day. With Arnold Schoenberg, who lived from 1874 to 1951 , the sonorous form and conception of the formation integrated by singing and piano comes to an end. He began his aesthetic explorations with Das Buch der hängenden Gärten. We have selected number 12 to illustrate all contemporary thinking about the lied of the 20th century. At the end of the twentieth century many languages follow one another, but the lied has lost interest in composers, and those who do have not brought anything new to the genre. Therefore, with Schoenberg's exemplification of the concept of lied, the journey of this musical form ends. The piano accompaniment that Schubert changed reaches its maximum evolution [12].

As many other composers did, Schoenberg spreads his compositional system to all his production, although this lied is not a faithful example. It is rather an atonal concept, but not a dodecaphonic one. In it we find vertical texture with a minor second in the left hand that will be repeated throughout the lied, both in the piano and in the voice. We can find it in a more evident way in measures 1,9 and 10 in the left hand, but also in the first and second measure in the right hand, or in the voice in measure 10.

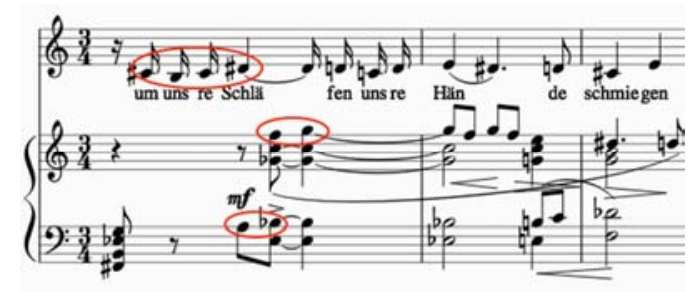

Figure 16. Measures 9 and 10.

Likewise, Schoenberg uses a lot of motor exploitation, and the second minor/major interval in different rhythms and placements is a constant. He will use it in the game of imitations, treating voice and piano as complementary instruments to each other to achieve the final result. This is the approach already stated by Schubert and which we have seen has been maintained in all languages until the twentieth century.

The piano and the voice have separate lines, i.e. they complete themselves in dialogue mode. However, in measure 16 the only unison of the whole work is produced. This is the moment when he is advising what he should not think. It is an important moment that Schoenberg wants to highlight.

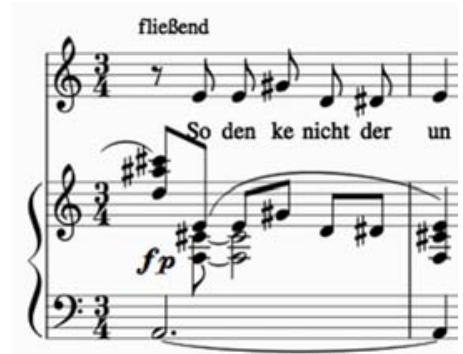

Figure 17. measure 16.

All the expressive weight of the poem is carried by the piano, just as we have seen in other composers. The melodic discourse of the voice in 20th century music is not a conception similar to the romantic one, and, as we said, the voice has a more secondary role than then. The instrumental 
music of the piano has surpassed the voice in the distribution of roles. If in the Baroque we spoke of just the opposite, here it is that the evolution of instrumental music has assumed the old roles of vocal music.

There are other highlights. On the one hand, the voice begins with an eminently declamatory tone at the beginning, thanks to the low sound density of the piano. The initial syncopations favour the descending phrasing that dialogues with the bass.

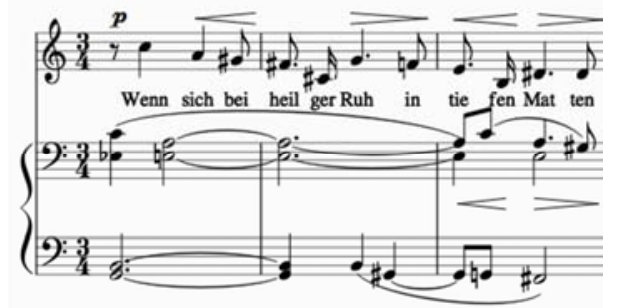

Figure 18. Measures 6 to 8.

After the first phrase it is the piano who in measure 9 takes the initiative with the indication 'molto espressivo', leaving the voice in a colored plane for the piano repeating the interval of second ascending or descending in different rhythms. In measure 12 , he reappears with an expressive tritone that will give him prominence in search of the forte that the piano has in the next measure. The next intervention is only by the piano that prepares the declamation of the voice in measure 16 in unison with the piano. From here until measure 21, it is the passage with the highest density of the work. We have distributed between the three voices a continuous rhythm of sixteenths and the directionality of the phrasing of both has changed upwards. Therefore, the sensation is to go further, culminating in the 20th bar for opposite movement. Once past, the piano remains alone in measure 22 with only one voice in descending order and in pianissimo.
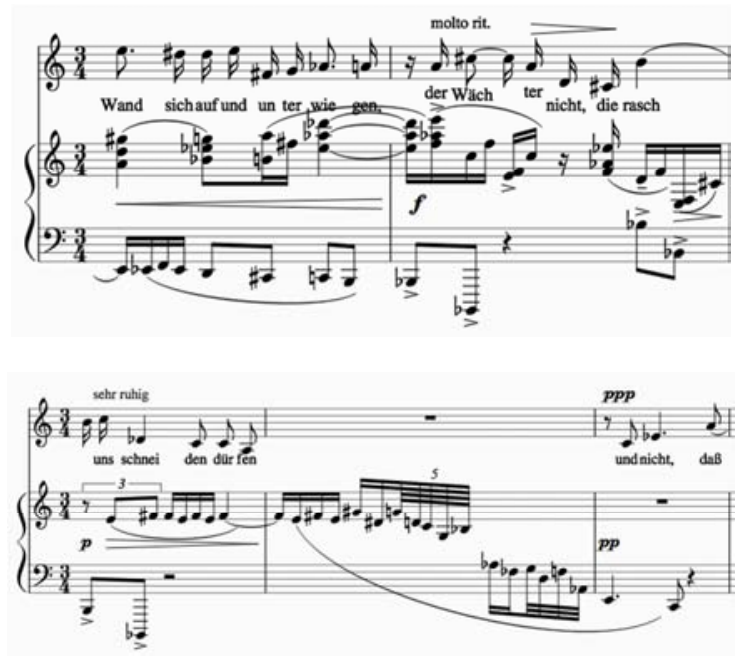

Figure 19. measures 19 to 23 .

The austerity reigns everywhere in the same way as the expressiveness, because this last phrase the piano must prepare an exquisite canvas to the voice. Finally, the piano concludes with a chord and the lowest $\mathrm{C}$ of the piano.

The whole atmosphere of the poem has been generated by the piano, and this will be the maxim in other composers such as Berg or Messiaen, who adapting to their style will reinforce this idea. The brevity will be its maxim, but it is the condensation of contemporary expressiveness.

\section{Results and Conclusions}

Throughout the previous section we have traveled through examples of the characteristics of piano accompaniment to the voice through all artistic styles. Let's see what Schubert meant in his conception of accompaniment.

In Schubert the idea of space and time is rewritten. We have already talked about it when analyzing its lieder. It is the piano part in charge of controlling and regulating this new format. It's almost orchestral rank equates the pianist to that of an orchestra conductor in charge of giving meaning to the lied. The little space with which he has ${ }^{1}$ associated to the emotional charge that infuses him, gives the impression to the listener of having listened to a work of greater magnitude, granting him therefore the condition of a greater musical form. Schubert's lied can be compared to an opera, an oratorio or pieces for solo piano. They are great miniature works where compositional, vocal and instrumental stylistics we can find everything we would find in a work of greater dimensions. The orchestra is reduced to the voice and the piano with the sound stage and transferred from the theater to the home. On many occasions we have seen how the difficulty of transferring all the orchestral sonorities to the piano greatly hinders their piano interpretation. Although it is pianistically interpretable, Schubert touches the impossible in its sound conception. Without a doubt he announces the piano and musical concept of Liszt, Wagner and Wolf. In the world of opera, the singer must approach the interpretation of a character during the whole work; in the lied, the difficulty increases since the interpreter must incarnate all the characters that each one of the songs has to develop, injecting the necessary color and sense.

On the other hand, Schubert's perfect musical description of both what the text contains and his imaginative parallel world leads us to talk about programmatic music. We have seen examples where the piano evokes equestrian figures, nocturnal atmospheres or the exaltation of joy. Theatricalization takes on a new meaning. If, as we have been narrating, the participation of the piano in the 18th century lieder was subordinated to the voice in order to provide it with a harmonic base, with Schubert the instrument is transformed acquiring a more than relevant role in all aspects: narrative-descriptive, rhythmic, regulator of tonalities, generator of sonorities-emotions. It can imitate the sensation of walking, the wind or the movement of a stream, the movements of a storm, the contrasts of joy or crying, dawn or dusk, but it is not limited to create a kind of background of the voice, but it rises in a symbol or

1 The lied is a brief form, however extensive some of Schubert may be. 
representation of the poem itself. Sometimes the piano provides an idea of the landscape and sometimes of the character's inner climate or both at the same time. This is where the conjunction between landscape and innerscape is established. This link is none other than that of the union between the popular song and the art song, the landscape and the inner world of the character, between the exterior and interior of the individual himself. Schubert achieves with this relationship the union of two worlds, the music of the people and the cultured music. It can be both simple and complex when, for example, it absorbs the simplified ideas of folklore and integrates a recitative, more characteristic of an oratory or a cantata. The responsibility of creating the whole figurative and expressive scenic atmosphere of the poem centred on the conception of sound, and not only the piano sound but the final result together with the voice. Schubert's concentration on the identification of the poet, the choice of the poem, the character and the voice make it the essence that distinguishes him from the lofty.

Schubert manifests himself as a true modulation artist. The use he makes of it has no equivalence and it is the piano that is in charge of managing this commission. In classicism, we find a dialogue between tonic and dominant, a questionanswer game, but faced with the need to musicalize a text with a great lyrical or dramatic content, Schubert introduces harmonic irregularities and open structures that somehow break with these schemes. It is the moment of unresolved dissonances or distant tonalities, characteristics that vindicate the freedom of the subject, maximum expression through music in Romanticism. Therefore, concepts such as order, clarity or the regularity sought by Classicism will be broken by Schubert through popular song. This popular song will be the one that will allow him to exalt in musical terms the ideas and affections of the poem. The changes of affection will be the excuse for his infinite ability to modulate, never exhausting the willingness of the listener to be surprised. The listener will be carried away by the different directions that Schubert transports us. For this, it is served not only at a harmonic level with the modulations, but as we have seen, with the polarity attraction of pedal notes placed both in the melody and in the piano. This multidirectionality gives the lied a character that is both open and defined. We do not think that before Schubert there was no directionality, but that this directionality becomes multifactorial in Schubert. In Classicism, Baroque or ancient Italian aria, it was the melody that moved within the tonal language with the attraction of the sensitive or dominant to resolve in the tonic. Schubert, on the other hand, treats directionality from many perspectives. As if it were a vanishing point in a two-dimensional image, Schubert focuses on one point all the melodic, rhythmic and harmonic lines placed both in the voice and on the piano. The effect he achieves is overwhelming. An example of this is the progressions that we have seen how he approaches them not only from a melodic, rhythmic or harmonic point of view, but from all of them simultaneously.

Schubert's compositional style raises the question of the spontaneity of his compositions. However, we think that he is very present, for example in his infinite ability to capture earthly pain. All the themes he chooses for his lieder tend to deal with problems that torment him personally, so we may be talking about a disordered autobiography. Therefore, he tends to thematize the sad and dark sides of life by recounting his experiences, his emotions, leaning on his main pillar, the piano. He did not describe the very acts of the plot, but the feelings of the protagonist having experienced certain acts such as exile, loving rejection, loneliness, madness and death. Schubert.

Schubert was the first to fuse the word with music in the lied. The concept of poetry was provided by Goethe, but Schubert elevated that rank by adding music through the piano. Schubert's exquisite and receptive sensitivity to poetry was masterfully expressed in the creation of his lieder. The poems achieved levels of expressiveness never imagined before when acquiring the sonorous universe. This Schubertian sound, his inexhaustible imagination in the composition of melodies, variety of styles and forms, modulations and accompaniment figures, are evidences of the expressive result of poetry. So is the fact that there are numerous versions of the same poem, as he was continually revising what he had composed.

The extreme fusion between text and music leads to the assignment of motifs for each character. We are in the anteroom of the Wagnerian leitmotif. These motifs, as we have already seen, are of a melodic-harmonic-rhythmic nature, and the difficulty lies in the fact that it must be the same pianist and the same singer who play the different roles, unlike Wagner who, with the orchestra and the numerous protagonists, have greater scope for discernment. It is a question of deepening the character of the poem and its expression. Fruit of the search of the expressive manifestation of the different elements of the lied, it concludes in granting to each character an own design based on the sound through the rhythm, the melody, the harmony and the accompaniment.

Schubert did not describe the very acts of the plot, but the feelings of the protagonist having suffered events such as exile, a loving rejection, loneliness, madness or death. The piano stands as the main character and the one who explains the whole content of the lied, which not only contains the text of the poem, but also a greater meaning that Schubert gives to it by giving another life, another vision of the poem through its lieder. On many occasions we have commented that they seem to be autobiographical works. Schubert recognizes himself as a pianist, and as a pianist, despite incorporating the voice, the piano is the main responsible for the expressive discourse of the work. Schubert tells the stories in the first person, himself, and he is embodied in the accompaniment of the piano.

From that moment on, we have seen how all subsequent composers use the best of themselves. We have commented that, although Mozart, Beethoven or Bach have composed works for voice and piano, the bulk of their artistic legacy is not in this form. However, since Schubert's change, composers such as Schumann, Wolf and Schoenberg have 
made the best of them available to the lied. Schubert left as much invention as possible in the genre of the lied and in the accompaniment for further development. We refer, for example, to Wagner's leitmotifs. Schubert, for example in Erlkönig, has already assigned rhythmic-melodic motifs to characters for identification. What Wagner did was to develop it and apply it not only in the composition for voice and piano but also in his grandiose operas. These circumstances take into account the thematic and harmonic configuration that Schubert imprints in the lied, and more specifically in the piano part. In this way, we have been able to specify the level of influence of Schubert's ideological proposal on composers contemporary to him and we have delimited the acquisition of the conception of Schubert's vocal piano accompaniment by later composers.
To sum up, we show you the following table that illustrates the evolution of the Lied, understanding both the vocal and the pianistic part, throughout history considering musical issues, both of a technical, vocal and pianistic nature. In the columns we relate the different artistic periods and in the rows we have the elements that we consider relevant to the level of study and development. We contemplate a specific column for Schubert, since it supposes a point of inflection in the approach of the lied to all the levels. With this comparative synthesis it is possible to observe the transformation of the lied through the passage of time through the different composers and epochs, both before and after Schubert, through the musical components that are integrated in the lied.

Table 1. Evolution of the lied throughout the history of music.

\begin{tabular}{|c|c|c|c|c|c|c|c|c|}
\hline & $\begin{array}{l}\text { Ancient } \\
\text { Italian Aria }\end{array}$ & Baroque & Classicism & Schubert & Romanticism & Post-Romanticism & Impressionism & $\begin{array}{l}\text { Post- } \\
\text { impressionism }\end{array}$ \\
\hline $\begin{array}{l}\text { Form/ } \\
\text { Structure }\end{array}$ & $\begin{array}{l}\text { - Binary } \\
\text { Lied }\end{array}$ & - Binary Lied & $\begin{array}{l}\text { Binary/Ternar } \\
\text { y Lied }\end{array}$ & $\begin{array}{l}\text { - Binary/ternary Lied } \\
\text { - Rondo } \\
\text { - Free } \\
\text { - Continuous } \\
\text { composition } \\
\text { (durchkomponiert) } \\
\text { - Cyclic Work } \\
\text { - Ostinatos }\end{array}$ & $\begin{array}{l}\text { - Binary/ternary Lied } \\
\text { - Rondo } \\
\text { - Free } \\
\text { - Continuous } \\
\text { composition } \\
\text { (durchkomponiert) }\end{array}$ & $\begin{array}{l}\text { - Ancient forms } \\
\text { - Free, adapts to the } \\
\text { poem } \\
\text { - Cyclic Work }\end{array}$ & $\begin{array}{l}\text { - Simplicity } \\
\text { - } \\
\text { Binary/Ternary } \\
\text { Lied }\end{array}$ & $\begin{array}{l}\text { - Simplicity } \\
\text { - Free }\end{array}$ \\
\hline Rhythm & $\begin{array}{l}\text { - Regular, } \\
\text { static, long } \\
\text { values }\end{array}$ & $\begin{array}{l}\text { - Regular, } \\
\text { static, but } \\
\text { with character } \\
\text { motives } \\
\text { - Ostinatos } \\
\text { - Varied } \\
\text { figuration }\end{array}$ & $\begin{array}{l}\text { - Constant } \\
\text { metric unit } \\
\text { and Ostinatos } \\
\text { - Contrasts } \\
\text { between lines } \\
\text { - Agogic } \\
\text { balance }\end{array}$ & $\begin{array}{l}\text { - Assigment of a } \\
\text { rhythmic-melodic } \\
\text { motif to each } \\
\text { character } \\
\text { - Progressions, } \\
\text { increases and } \\
\text { decreases } \\
\text { - Polyrhythm and } \\
\text { rhythmic variety }\end{array}$ & $\begin{array}{l}\text { - Ostinatos } \\
\text { - Varied metrics }\end{array}$ & $\begin{array}{l}\text { - Polyrhythm } \\
\text { - Varied figuration } \\
\text { - Ostinatos }\end{array}$ & $\begin{array}{l}\text { - Polyrhythm } \\
\text { - Varied } \\
\text { figuration }\end{array}$ & $\begin{array}{l}\text { - Free } \\
\text { - Amalgam } \\
\text { compasses }\end{array}$ \\
\hline $\begin{array}{l}\text { Melody/ } \\
\text { Voice }\end{array}$ & $\begin{array}{l}\text { - Dramatic } \\
\text { weight on } \\
\text { the voice } \\
\text { - Recitative } \\
\text { - Reduced } \\
\text { tessitura }\end{array}$ & $\begin{array}{l}\text { - Wider range } \\
\text { of tessitura } \\
\text { - Low } \\
\text { relevance in } \\
\text { the set } \\
\text { - } \\
\text { Chromatisms } \\
\text { - Melismas }\end{array}$ & $\begin{array}{l}\text { - Existence of } \\
\text { three melodic } \\
\text { lines: the } \\
\text { voice and two } \\
\text { of the piano } \\
\text { - Natural } \\
\text { phrasing } \\
\text { - Vocal } \\
\text { virtuosity } \\
\text { - Operistic } \\
\text { influence } \\
\text { - Distribution } \\
\text { of the main } \\
\text { melody } \\
\text { between voice } \\
\text { and piano }\end{array}$ & $\begin{array}{l}\text { - Wide tessitura } \\
\text { - In the same Lied } \\
\text { plays several } \\
\text { characters } \\
\text { - Melodism, } \\
\text { declamation } \\
\text { - Melodic-harmonic } \\
\text { chromatism } \\
\text { - Different directions }\end{array}$ & $\begin{array}{l}\text { - Separate poetic ideas } \\
\text { - Wide tessitura } \\
\text { - Melodism, } \\
\text { declamation } \\
\text { - Melodic-harmonic } \\
\text { chromatism }\end{array}$ & $\begin{array}{l}\text { - Letimotif } \\
\text { (Wagner) } \\
\text { - Average register } \\
\text { and tessitura } \\
\text { - Expressionist } \\
\text { language } \\
\text { - Relevant weight } \\
\text { of the text } \\
\text { - Instrumental } \\
\text { character } \\
\text { - Wide Tessitura } \\
\text { - Chromatism } \\
\text { - The voice is one } \\
\text { more line in the } \\
\text { counterpoint } \\
\text { framework }\end{array}$ & $\begin{array}{l}\text { - Declamation } \\
\text { - Exoticism } \\
\text { - Chromatism } \\
\text { - Average } \\
\text { register and } \\
\text { tessitura }\end{array}$ & $\begin{array}{l}\text { - Sprechgesang } \\
\text { (spoken } \\
\text { language) } \\
\text { - The voice is } \\
\text { one more line } \\
\text { in the } \\
\text { counterpoint } \\
\text { framework } \\
\text { - Chromatism } \\
\text { - Average } \\
\text { register and } \\
\text { tessitura }\end{array}$ \\
\hline Harmony & $\begin{array}{l}\text { - Basic with } \\
\text { triad/four- } \\
\text { triad chords } \\
\text { - Few } \\
\text { modulations } \\
\text { - Tonal } \\
\text { degrees }\end{array}$ & $\begin{array}{l}\text { - } \\
\text { podulations, } \\
\text { progressions, } \\
\text { and } \\
\text { dissonances } \\
\text { - Important as } \\
\text { a contrasting } \\
\text { and } \\
\text { expressive } \\
\text { element } \\
\text { - Tonal } \\
\text { degrees }\end{array}$ & $\begin{array}{l}\text { - Basic with } \\
\text { triad/four- } \\
\text { triad chords } \\
\text { - Tonal } \\
\text { degrees } \\
\text { - Simplicity, } \\
\text { clarity }\end{array}$ & $\begin{array}{l}\text { - Importance of } \\
\text { modulations as an } \\
\text { expressive resource } \\
\text { - Tension/distension } \\
\text { set } \\
\text { - All compositional } \\
\text { resources available to } \\
\text { the Lied } \\
\text { - Pedal notes } \\
\text { - Altered harmony }\end{array}$ & $\begin{array}{l}\text { - Pedal notes } \\
\text { - Altered harmony } \\
\text { - Chromatisms }\end{array}$ & $\begin{array}{l}\text { - Complete work of } \\
\text { art (Wagner) } \\
\text { - Altered harmony } \\
\text { moving away from } \\
\text { tonality } \\
\text { - Tonal vagueness } \\
\text { - Evolution of the } \\
\text { concept of } \\
\text { dissonance }\end{array}$ & $\begin{array}{l}\text { - All types of } \\
\text { scales and } \\
\text { chords } \\
\text { - Extension of } \\
\text { the concept of } \\
\text { dissonance as } \\
\text { an expressive } \\
\text { element - } \\
\text { Abandonment } \\
\text { of tonal } \\
\text { polarity }\end{array}$ & $\begin{array}{l}\text { - New melodic, } \\
\text { harmonic, } \\
\text { sonorous and } \\
\text { rhythmic } \\
\text { languages }\end{array}$ \\
\hline
\end{tabular}




\begin{tabular}{|c|c|c|c|c|c|c|c|c|}
\hline & $\begin{array}{l}\text { Ancient } \\
\text { Italian Aria }\end{array}$ & Baroque & Classicism & Schubert & Romanticism & Post-Romanticism & Impressionism & $\begin{array}{l}\text { Post- } \\
\text { impressionism }\end{array}$ \\
\hline Texture & $\begin{array}{l}\text { - Choral } \\
\text { - } \\
\text { Homophony }\end{array}$ & $\begin{array}{l}\text { - Basso } \\
\text { continuous } \\
\text { - Adaptation } \\
\text { of the } \\
\text { accompanime } \\
\text { nt pattern } \\
\text { according to } \\
\text { the expressive } \\
\text { moment of } \\
\text { the work } \\
\text { - Arpegiated } \\
\text { chords } \\
\text { - Influence of } \\
\text { the oratorio } \\
\text { on the voice- } \\
\text { piano duo }\end{array}$ & $\begin{array}{l}\text { - Basso } \\
\text { Alberti } \\
\text { - Harmonic } \\
\text { deployment } \\
\text { - Different } \\
\text { contrasted } \\
\text { accompanime } \\
\text { nt patterns } \\
\text { - Pianistic } \\
\text { orchestral } \\
\text { character } \\
\text { (Beethoven) }\end{array}$ & $\begin{array}{l}\text { - Endless variety of } \\
\text { accompaniment } \\
\text { patterns } \\
\text { - Relationship } \\
\text { between texture and } \\
\text { character of the text } \\
\text { - Orchestral character } \\
\text { - Expressive search } \\
\text { according to texture }\end{array}$ & $\begin{array}{l}\text { - Great variety of } \\
\text { patterns } \\
\text { - Relationship } \\
\text { between texture and } \\
\text { character of the text } \\
\text { - Expressive search } \\
\text { according to texture }\end{array}$ & $\begin{array}{l}\text { - Great variety of } \\
\text { patterns } \\
\text { - Operistic and } \\
\text { orchestral } \\
\text { conception } \\
\text { - Relationship } \\
\text { between texture } \\
\text { and character of the } \\
\text { text } \\
\text { - Expressive search } \\
\text { according to } \\
\text { texture }\end{array}$ & $\begin{array}{l}\text { - Breadth and } \\
\text { dynamic sound } \\
\text { - Shared use of } \\
\text { motifs between } \\
\text { voice and piano } \\
\text { - Expressive } \\
\text { search } \\
\text { according to } \\
\text { texture }\end{array}$ & $\begin{array}{l}\text { - Breadth and } \\
\text { dynamic sound } \\
\text { - Shared use of } \\
\text { motifs between } \\
\text { voice and piano } \\
\text { - Expressive } \\
\text { search } \\
\text { according to } \\
\text { texture }\end{array}$ \\
\hline Tone & $\begin{array}{l}\text { - Unison of } \\
\text { piano and } \\
\text { voice } \\
\text { - Reduced } \\
\text { register }\end{array}$ & $\begin{array}{l}\text { - Redoubling } \\
\text { of the melody } \\
\text { by the piano } \\
\text { - Reduced } \\
\text { register }\end{array}$ & $\begin{array}{l}\text { - Independent } \\
\text { registers } \\
\text { between } \\
\text { piano and } \\
\text { voice } \\
\text { - Expansion } \\
\text { tessitura } \\
\text { - Unisons }\end{array}$ & $\begin{array}{l}\text { - Piano orchestral } \\
\text { emulation } \\
\text { - Choice of sound } \\
\text { palette according to } \\
\text { the voice and } \\
\text { character of the Lied } \\
\text { - Exchange of register } \\
\text { between voice and } \\
\text { piano } \\
\text { - } \\
\text { Unison/independence } \\
\text { voice-piano }\end{array}$ & $\begin{array}{l}\text { - Choice of sound } \\
\text { palette according to } \\
\text { the voice and } \\
\text { character of the Lied } \\
\text { - Exchange of register } \\
\text { between voice and } \\
\text { piano } \\
\text { - } \\
\text { Unison/independence } \\
\text { voice-piano }\end{array}$ & $\begin{array}{l}\text { - Piano orchestral } \\
\text { emulation } \\
\text { - Emulation of } \\
\text { other instruments } \\
\text { - Choice of sound } \\
\text { palette according to } \\
\text { the voice and } \\
\text { character of the } \\
\text { Lied } \\
\text { - Exchange of } \\
\text { register between } \\
\text { voice and piano } \\
\text { - } \\
\text { Unison/independen } \\
\text { ce voice-piano }\end{array}$ & $\begin{array}{l}\text { - Colourful and } \\
\text { subtle } \\
\text { sonorities of } \\
\text { both the piano } \\
\text { and the voice, } \\
\text { both } \\
\text { individually } \\
\text { and together }\end{array}$ & $\begin{array}{l}\text { - Exchange of } \\
\text { register } \\
\text { between voice } \\
\text { and piano } \\
\text { - Independence } \\
\text { voice-piano } \\
\text { - } \\
\text { Dodecaphonic } \\
\text { counterpoint }\end{array}$ \\
\hline Theme & $\begin{array}{l}\text { - Love } \\
\text { - Mythology }\end{array}$ & $\begin{array}{l}\text { - Love } \\
\text { - Sacred } \\
\text { topics }\end{array}$ & $\begin{array}{l}\text { - Love } \\
\text { - Descriptive }\end{array}$ & $\begin{array}{l}\text { - Description of } \\
\text { moods } \\
\text { - Love } \\
\text { - Mythology }\end{array}$ & - Love & $\begin{array}{l}\text { - Love } \\
\text { - Descriptions } \\
\text { - Nature } \\
\text { - Customary }\end{array}$ & $\begin{array}{l}\text { - Love } \\
\text { - Nature } \\
\text { - Onirism } \\
\text { - Customary }\end{array}$ & - Society \\
\hline
\end{tabular}

\section{References}

[1] CASABLANCAS, B. (1997): "Quietud y trance. En torno a la última obra para piano de Franz Schubert (notas sobre los albores del romanticismo musical)", en Quodlibet, revista de música, vol. 7. Universidad Alcalá de Henares.
[2] CLARK, S. (2011): Analyzing Schubert. Cambridge University Press.

[3] DAMSCHRODER, D. (2014): Harmony in Schubert. Cambridge University Press.

[4] FISCHER-DIESKAU, D. (1989): Los lieder de Schubert. Alianza Música. Madrid. 
[5] DAVERIO, J. (2002): Crossing paths: Schubert, Schumann and Brahms. Oxford University Press.

[6] ELSON, L. C. (1888): History of German Song. New England Conservatory of Music. Boston.

[7] YOUENS, S. (1992): Hugo Wolf: the vocal music. Princeton University Press.

[8] HALLMARK, R. (1996): German lieder in the nineteenth century. Schirmer Books, Londres.
[9] SAMS, E. (1993): The songs of Hugo Wolf. Indiana University Press. 1993.

[10] NOSKE, F. (2012): French song from Berlioz to Duparc. Dover Publications, Nueva York.

[11] BERNAC, P. (1978): The interpretation of French Song. W. W. Norton \& Company's editor, Nueva York.

[12] FRISCH, W. (1993): The early works of Arnold Schoenberg, 1893-1908. University of California Press, Berkeley. 